\title{
PENINGKATAN PERTUMBUHAN DAN HASIL KACANG TANAH (Arachis hypogea L.) AKIBAT PEMBERIAN TAKARAN PUPUK KANDANG DOMBA DAN KONSENTRASI PUPUK ORGANIK CAIR TRUBUS
}

\author{
Improvement Of Growth And Due Peanut (Arachis hypogea L.) To The Granting \\ Of Measuring Concentration Of Fertilizer Coop Sheep And Organic Liqiud \\ Fertilizer TRUBUS \\ Raden Budiasih \\ Fakultas Pertanian, Universitas Winaya Mukti \\ budiasihenty@gmail.com
}

\begin{abstract}
We report the dose of sheep manure and POC concentration Poster which aims to study changes in the dose of sheep manure and Poster POC concentration on growth and yield of peanut (Arachis hypogea L.). This research is compiled in a randomized block design (RAK) factorial design consisting of two factors. The first factor sheep manure dosage form consists of three levels ie d1 $\left(5 \mathrm{t} \mathrm{ha}^{-1}\right), \mathrm{d} 2\left(10 \mathrm{ton} \mathrm{ha}^{-1}\right)$ and $\mathrm{d} 3\left(15 \mathrm{ton} \mathrm{ha}^{-1}\right)$. The second factor in the form of the concentration of liquid organic fertilizer Poster consists of three levels ie p1 $\left(1 \mathrm{ml} \mathrm{l}^{-1}\right)$, p2 $\left(3 \mathrm{ml} \mathrm{l}^{-1}\right)$ and P3 $\left(5 \mathrm{ml} \mathrm{l}^{-1}\right)$, respectively - each combination treatment was repeated 3 times. Different test average - average use multiple range test duncant 5\% significance level. Award dose sheep manure and POC concentration Poster melihatkan their interaction on plant height 9 MST, pong number per plant and weight of pods per plant, giving a high dose of manure that requires concentration POC rendah. Secara an Independent Award dose effect of manure 10 ton $\mathrm{ha}^{-1}$ and 15 ton $\mathrm{ha}^{-1}$ showed the best effect on the plant height ages 5 and 7 MST MST, the percentage of pithy pods and number of seeds per plant.
\end{abstract}

Keywords: Peanut, Manure Sheep and POC Poster

\section{PENDAHULUAN}

Kacang tanah merupakan tanaman leguminosa yang perannya cukup penting di Indonesia setelah kedelai. Kacang tanah merupakan sumber proten dan lemak nabati yang penggunaannya cukup luas, selain sebagai bahan cimilan banyak juga digunakan sebagai bahan baku industri dan makan ternak.

Berdasarkan data yang diperoleh Ditjen Tanaman Pangan (2012) kebutuhan kacang tanah Indonesia terus meningkat rata-rata 900.000 ton dengan produksi rata-rata 783.110 ton setiap tahun, sehingga produksi nasional hanya mampu memenuhi sekitar $87,01 \%$ dari kebutuhan kacang tanah. Pada tahun 2011, produksi dalam negeri sebesar 691.289 ton yang diperoleh dari luas panen 539.459 ha. Produktivitas kacang tanah Indonesia baru mencapai 1,28 $\mathrm{t} \mathrm{ha}^{-}$ ${ }^{1}$. Rendahnya produktivitas kacang tanah disebabkan oleh penanaman sebagian besar dilakukan pada lahan - lahan marginal yang memiliki kandungan bahan organik rendah. 
Secara umum kacang tanah dapat dibudidayakan pada berbagai jenis tanah. Pada lahan yang subur, melalui perbaikan kesuburan tanah dan cara budidaya produktivitas kacang tanah mencapai 2,5-4 t/ha. Sedangkan pada lahan marjinal, perbaikan kesuburan tanah dan cara budidaya produktivitas tanah dapat mencapai 1,8 - 2,5 tha (Wijanarko et al. 2013). Perbaikan kesuburan tanah memungkinkan tanah yang akan diusahakan memiliki struktur tanah yang ringan dan mengandung unsur hara makro dan mikro yang cukup. Kondisi demikian mendukung diperolehnya pertumbuhan dan produksi yang optimal. Tingkat kemasaman tanah yang optimal untuk pertumbuhan kacang tanah adalah $\mathrm{pH} 5,0-6,5$. Tanah yang gembur dan berstruktur ringan akan memudahkan masuknya ginofor ke dalam tanah, akar dan polong dapat berkembang optimal, dan memudahkan saat panen (Yurnalis 2006).

Perbaikan kesuburan tanah dapat dilakukan dengan cara menambahakan pupuk organik ke dalam tanah baik berupa pupuk organik padat maupun pupuk organik cair. Pengujian kedua jenis pupuk ini terhadap kacang tanah merupakan hal yang menarik karena setiap jenis pupuk akan menunjukkan pengaruh yang berbeda terhadap pertumbuhan dan hasil kacang tanah.

\section{METODE PENELITIAN}

Penelitian ini dilaksanakan di Kebun Percobaan Fakultas Pertanian Universitas Winaya Mukti Kec. Tanjungsari, Kabupaten Sumedang dengan ketinggian 850 mdpl, dilaksankan dari bulan sampai bulan
2014. Bahan yang digunakan dalam penelitian ini meliputi benih kacang tanah asal Jepang, pupuk kandang domba, pupuk organik cair trubus. Alatalat yang digunakan berupa cangkul, penggaris, timbangan dan alat tulis.

Rancangan lingkuan yang diguanakan adalah Rancangan Acak Kelompok (RAK) pola Faktorial yang terdiri dari 2 faktor. Faktor pertama berupa takaran pupuk kandang domba terdiri dari 3 taraf yaitu $\mathrm{d}_{1}\left(5\right.$ ton ha $\left.{ }^{-1}\right), \mathrm{d}_{2}$ $\left(10\right.$ ton ha $\left.{ }^{-1}\right)$ dan $d_{3}\left(15\right.$ ton ha $\left.{ }^{-1}\right)$. Faktor kedua berupa konsentrasi pupuk organik cair trubus terdiri dari 3 taraf yaitu $\mathrm{p}_{1}(1$ $\left.\mathrm{ml} \mathrm{l}^{-1}\right), \mathrm{p}_{2}\left(3 \mathrm{ml} \mathrm{l}^{-1}\right)$ dan $\mathrm{p}_{3}\left(5 \mathrm{ml} \mathrm{l}^{-1}\right)$, masing - masing kombinasi perlakuan diulang sebanyak 3 kali. Uji beda rata rata menggunakan uji jarak berganda duncant taraf nyata $5 \%$. Respons yang diamati berupa tinggi tanaman, jumlah biji per tanaman, persentase polong bernas, jumlah polong per tanaman dan berat polong per tanaman.

\section{HASIL DAN PEMBAHASAN}

\section{Hasil Penelitian Tinggi Tanaman}

Hasil analisis varian menunjukkan pemberian pupuk kandang domba dan pupuk organik cair trubus berpengaruh nyata pada tinggi tanaman umur 3 MST, 5 MST, 7 MST dan 9 MST. Dimana berdasarkan uji jarak berganda duncant tinggi tanaman umur 3 MST, 5 MST, 7 MST tidak memperlihatkan interkasi namun berdasarkan efek madiri menunjukkan perbedaan yang nyata, sedangkan tinggi tanaman umur 9 MST menunjukkan interaksi. Selanjunya hasil analisis dapat dilihat pada Tabel 1 dan Tabel 2. 
Tabel 1. Pengaruh Pupuk Kandang Domba dan Pupuk Organik Cair terhadap Tinggi Tanaman Umur 3 MST, 5 MST, 7 MST.

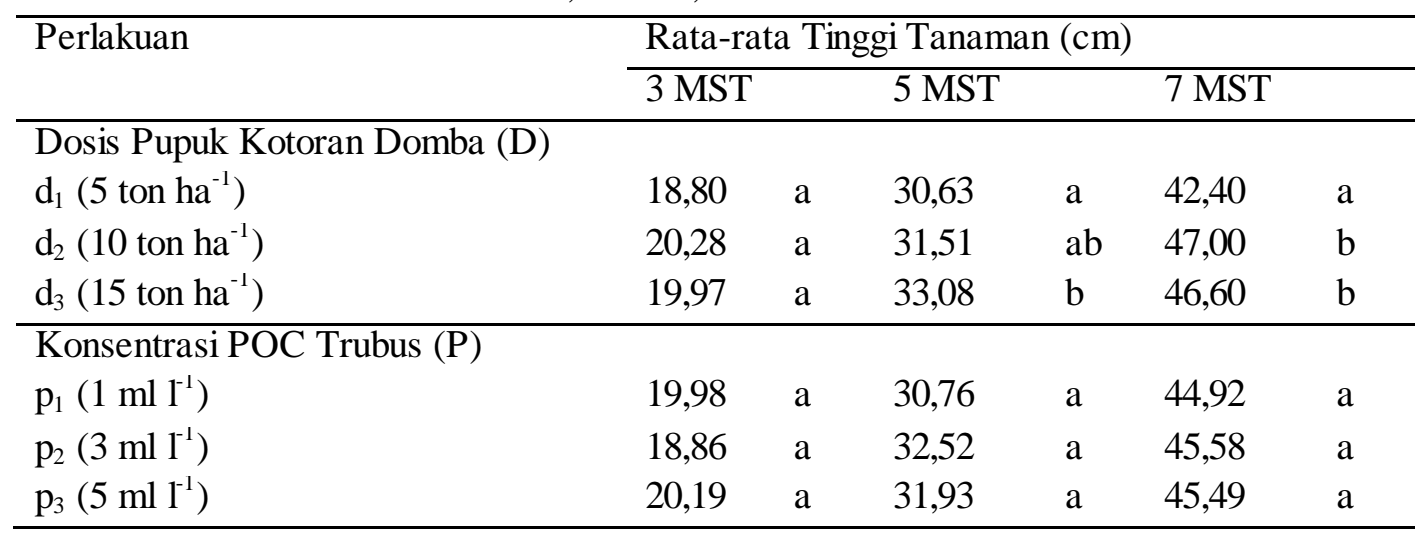

Tabel 1 secara efek madiri takaran pupuk kotoran domba pada umur 35 MST dan 7 MST menunjukkan perbedaan yang nyata, dimana perlakuan $\mathrm{d}_{2}\left(10\right.$ ton $\left.\mathrm{ha}^{-1}\right)$ dan $\mathrm{d}_{3}\left(15\right.$ ton $\left.\mathrm{ha}^{-1}\right)$ merupakan perlakuan yang menunjukkan tinggi tanaman tertinggi dibandingan perlakuan $\mathrm{d}_{1}\left(5\right.$ ton $\left.\mathrm{ha}^{-1}\right)$. Sedangkan untuk pengamatan tinggi

Tabel 2. Pengaruh Pupuk Kandang Domba dan Pupuk Organik Cair terhadap Tinggi Tanaman Umur 3 MST, 5 MST, 7 MST.

\begin{tabular}{|c|c|c|c|c|c|c|}
\hline \multirow[t]{2}{*}{ Dosis Pupuk Kotoran Domba (D) } & \multicolumn{6}{|c|}{ Konsentrasi POC Trubus (P) } \\
\hline & \multicolumn{2}{|c|}{$\mathrm{p} 1\left(1 \mathrm{ml} \mathrm{l}^{-1}\right)$} & \multicolumn{2}{|c|}{$\mathrm{p} 2\left(3 \mathrm{ml} \mathrm{l}^{-1}\right)$} & \multicolumn{2}{|c|}{$\mathrm{p} 3\left(5 \mathrm{ml} \mathrm{l}^{-1}\right)$} \\
\hline \multirow[t]{2}{*}{ d1 $\left(5\right.$ ton ha $\left.^{-1}\right)$} & 49,43 & $\mathrm{a}$ & 54,97 & $\mathrm{a}$ & 52,83 & $\bar{a}$ \\
\hline & A & & B & & B & \\
\hline \multirow[t]{2}{*}{ d2 $\left(10\right.$ ton $\left.\mathrm{ha}^{-1}\right)$} & 55,53 & $\mathrm{~b}$ & 56,83 & $\mathrm{a}$ & 53,43 & $\mathrm{a}$ \\
\hline & $\mathrm{AB}$ & & B & & $\mathrm{a}$ & \\
\hline \multirow[t]{2}{*}{$\mathrm{d} 3\left(15\right.$ ton $\left.\mathrm{ha}^{-1}\right)$} & 57,23 & $\mathrm{~b}$ & 54,47 & $\mathrm{a}$ & 54,37 & $\mathrm{a}$ \\
\hline & $\mathrm{B}$ & & A & & A & \\
\hline
\end{tabular}

Tabel 9. memperlihatkan bahwa pemberian pupuk kandang domba takaran $5 \mathrm{t} \mathrm{ha}^{-1}$, konsentrasi POC trubus menunjukkan perbedaan yang nyata, dimana taraf $\mathrm{p}_{2}$ dan $\mathrm{p}_{3}$ memperlihatkan tinggi tanaman tertinggi dan berbeda tidak nyata dengan taraf $p_{1}$. Taraf $d_{2}$ tanaman umur 3 MST menunjukkan perbedaan tidak nyata dimana perlakuan $d_{1}$ sama dengan perlakuan $d_{2}$ dan $d_{3}$.

Taraf perlakuan pupuk organik cair trubus pada tinggi tanaman secara efek madiri menunjukkan perbedaan yang tidak nyata, dimana taraf $\mathrm{p}_{1}$ sama dengan taraf lainnya yakni $\mathrm{p}_{2}$ dan $\mathrm{p}_{3}$. 
Perlakuan konsentrasi POC trubus taraf $\mathrm{p}_{1}$ menunjukkan tinggi tanaman terbaik pada taraf pupuk kandang domba $\mathrm{d}_{2}$ dan $\mathrm{d}_{3}$ serta dengan taraf perlakuan lainnya menunjukkan perbedaan yang tidak nyata.

\section{Persentase Polong Bernas}

Hasil analisis varian untuk pengamatan persentase polong bernas menunjukkan pengaruh yang nyata. Dimana hasil analisis uji jarak berganda duncant disajikan pada Tabel 3.

Tabel 3. Pengaruh Pupuk Kandang Domba dan Pupuk Organik Cair terhadap Persentase Polong Bernas.

\begin{tabular}{lll}
\hline Perlakuan & Rata-rata Jumlah Biji per Tanaman \\
\hline Dosis Pupuk Kotoran Domba (D) & & \\
$\mathrm{d}_{1}(5$ ton ha- & \\
$\mathrm{d}_{2}\left(10 \mathrm{ton} \mathrm{ha}^{-1}\right)$ & 39,18 & $\mathrm{a}$ \\
$\mathrm{d}_{3}\left(15\right.$ ton ha $\left.^{-1}\right)$ & 44,47 & $\mathrm{~b}$ \\
\hline Konsentrasi POC Trubus (P) & 42,66 & $\mathrm{ab}$ \\
$\mathrm{p}_{1}\left(1 \mathrm{ml} \mathrm{l}^{-1}\right)$ & & \\
$\mathrm{p}_{2}\left(3 \mathrm{ml} \mathrm{l}^{-1}\right)$ & 41,27 & $\mathrm{a}$ \\
$\mathrm{p}_{3}\left(5 \mathrm{ml} \mathrm{l}^{-1}\right)$ & 41,58 & $\mathrm{a}$ \\
\hline
\end{tabular}

Tabel 3. memperlihatkan bahwa secara efek mandiri takaran pupuk kandang domba terhadap persentase polong bernas memperlihatkan perbedaan yang nyata. Dimana taraf perlakuan $d_{2}$ merupakan taraf yang menunjukkan respons terbaik dan berbeda nyata dengan taraf $d_{1}$, tetapi berbeda tidak nyata dengan taraf $d_{3}$. Sedangkan perlakuan konsentrasi POC trubus menunjukkan pengaruh yang tidak bebeda nyata terhadap semua taraf perlakuan.

\section{Jumlah Polong per Tanaman}

Hasil analisis varian menunjukkan pemberian pupuk kandang domba dan pupuk organik cair trubus berpengaruh nyata pada pengamatan jumlah polong per tanaman. Selanjutnya uji jarak berganda duncant disajikan pada Tabel 4.

Tabel 4. terlihat bahwa pada pemberian takaran pupuk kandang domba taraf $d_{2}$ dan $d_{3}$, pada konsentrasi POC trubus taraf $\mathrm{p}_{1}$ dan $\mathrm{p}_{2}$ memiliki jumlah polong terbanyak meskipun pada $\mathrm{d}_{2}$, taraf $\mathrm{p}_{1}$ berbeda tidak nyata dengan taraf $d_{1}$. Perlakuan takaran pupuk domba terhadap taraf $\mathrm{p}_{3}$ menunjukkan perbedaan yang tidak nyata. 
Tabel 4. Pengaruh Pupuk Kandang Domba dan Pupuk Organik Cair terhadap Persentase Polong Bernas.

\begin{tabular}{lllllll}
\hline Dosis Pupuk Kotoran Domba (D) & \multicolumn{5}{l}{ Konsentrasi POC Trubus (P) } \\
\cline { 2 - 7 } & \multicolumn{4}{l}{$\mathrm{p}_{1}\left(1 \mathrm{ml} \mathrm{l}^{-1}\right)$} & $\mathrm{p}_{2}\left(3 \mathrm{ml} \mathrm{l}^{-1}\right)$ & $\mathrm{p}_{3}\left(5 \mathrm{ml} \mathrm{l}^{-1}\right)$ \\
\hline $\mathrm{d}_{1}\left(5\right.$ ton ha $\left.^{-1}\right)$ & 21,60 & $\mathrm{a}$ & 23,00 & $\mathrm{a}$ & 27,67 & $\mathrm{a}$ \\
& A & & A & & B & \\
$\mathrm{d}_{2}\left(10\right.$ ton ha $\left.^{-1}\right)$ & 24,33 & $\mathrm{ab}$ & 29,60 & $\mathrm{~b}$ & 29,93 & $\mathrm{a}$ \\
& A & & $\mathrm{B}$ & & $\mathrm{B}$ & \\
$\mathrm{d}_{3}\left(15\right.$ ton $\left.^{-1}\right)$ & 28,07 & $\mathrm{~b}$ & 32,87 & $\mathrm{~b}$ & 26,40 & $\mathrm{a}$ \\
& AB & & B & & A & \\
\hline
\end{tabular}

Faktor konsentrasi POC trubus pada taraf $d_{1}$, taraf $p_{3}$ menunjukkkan jumlah polong per tanaman terbaik dan berbeda nyata dengan perlakuan lainya. Taraf $\mathrm{p}_{3}$ dan $\mathrm{p}_{4}$ pada taraf $\mathrm{d}_{2}$ merupakan taraf perlakuan yang memberikan jumlah polong per tanaman terbaik dan berbeda nyata dengan taraf $\mathrm{p}_{1}$. Pada taraf $\mathrm{p}_{2}$, taraf $\mathrm{d}_{3}$ merupakan taraf yang memberikan perlakuan terbaik dan berbeda nyata dengan taraf $\mathrm{p}_{1}$ serta berbeda nyata dengan $\mathrm{p}_{3}$.

\section{Bobot Polong per Tanaman}

Hasil analisis varian menunjukkan pemberian pupuk kandang domba dan pupuk organik cair trubus berpengaruh nyata pada pengamatan bobot polong per tanaman. Selanjutnya uji jarak berganda duncant disajikan pada Tabel 5.

Tabel 5. memperlihatkan bahwa taraf $\mathrm{d}_{2}$ dan $\mathrm{d}_{3}$, pada taraf $\mathrm{p}_{1}$ dan $\mathrm{p}_{2}$ menunjukkan bobot pong per tanaman terbaik dan berbeda nyata dengan taraf perlakuan lainya. Sedangkan perlakuan kosentrasi POC trubus taraf $t_{3}$ menunjukkan bobot polong per tanaman terbaik pada taraf $\mathrm{d}_{1}$ dan berbeda tidak nyata dengan perlakuan lainya.

Tabel 4. Pengaruh Pupuk Kandang Domba dan Pupuk Organik Cair terhadap Bobot Polong per Tanaman.

\begin{tabular}{|c|c|c|c|c|c|c|}
\hline \multirow[t]{2}{*}{ Dosis Pupuk Kotoran Domba (D) } & \multicolumn{6}{|c|}{ Konsentrasi POC Trubus (P) } \\
\hline & \multicolumn{2}{|c|}{$\mathrm{p}_{1}\left(1 \mathrm{ml} \mathrm{l}^{-1}\right)$} & \multicolumn{2}{|c|}{$\mathrm{p}_{2}\left(3 \mathrm{ml} \mathrm{l}^{-1}\right)$} & \multicolumn{2}{|c|}{$\mathrm{p}_{3}\left(5 \mathrm{ml} \mathrm{l}^{-1}\right)$} \\
\hline \multirow[t]{2}{*}{$d_{1}\left(5\right.$ ton $\left.h^{-1}\right)$} & 100,00 & $\mathrm{a}$ & 100,00 & $\bar{a}$ & 193,33 & $\mathrm{a}$ \\
\hline & A & & A & & B & \\
\hline \multirow[t]{2}{*}{$\mathrm{d}_{2}\left(10\right.$ ton $\left.\mathrm{ha}^{-1}\right)$} & 160,00 & $\mathrm{~b}$ & 180,00 & $\mathrm{~b}$ & 186,67 & $\mathrm{a}$ \\
\hline & A & & $\mathrm{A}$ & & A & \\
\hline \multirow[t]{2}{*}{$\mathrm{d}_{3}\left(15\right.$ ton $\left.\mathrm{ha}^{-1}\right)$} & 170,00 & $\mathrm{~b}$ & 160,00 & $\mathrm{~b}$ & 146,67 & $\mathrm{a}$ \\
\hline & A & & A & & A & \\
\hline
\end{tabular}


6 |PASPALUM VOLIIINo. 2 September 2015

Tabel 3. Pengaruh Pupuk Kandang Domba dan Pupuk Organik Cair terhadap Jumlah Biji per Tanaman.

\begin{tabular}{|c|c|c|}
\hline \multirow{2}{*}{$\begin{array}{l}\text { Perlakuan } \\
\text { Dosis Pupuk Kotoran Domba (D) }\end{array}$} & \multicolumn{2}{|c|}{ Rata-rata Jumlah Biji per Tanaman } \\
\hline & & \\
\hline $\mathrm{d}_{1}\left(5\right.$ ton $\left.\mathrm{ha}^{-1}\right)$ & 22,82 & a \\
\hline $\mathrm{d}_{2}\left(10\right.$ ton $\left.\mathrm{ha}^{-1}\right)$ & 29,31 & $\mathrm{~b}$ \\
\hline $\mathrm{d}_{3}\left(15\right.$ ton $\left.\mathrm{ha}^{-1}\right)$ & 31,80 & $\mathrm{~b}$ \\
\hline Konsentrasi POC Trubus (P) & & \\
\hline $\mathrm{p}_{1}\left(1 \mathrm{ml} \mathrm{l}^{-1}\right)$ & 28,07 & $\mathrm{a}$ \\
\hline $\mathrm{p}_{2}\left(3 \mathrm{ml} \mathrm{l}^{-1}\right)$ & 25,47 & a \\
\hline $\mathrm{p}_{3}\left(5 \mathrm{ml} \mathrm{l}^{-1}\right)$ & 30,40 & a \\
\hline
\end{tabular}

\section{Jumlah Biji per Tanaman}

Hasil analisis varian untuk pengamatan jumlah biji per tanaman menunjukkan pengaruh yang nyata. Dimana hasil analisis uji jarak berganda duncant disajikan pada Tabel 3.

Tabel 3. memperlihatkan bahwa secara efek mandiri takaran pupuk kandang domba terhadap jumlah biji per tanaman memperlihatkan perbedaan yang nyata. Dimana taraf perlakuan $\mathrm{d}_{2}$ dan $\mathrm{d}_{3}$ merupakan taraf yang menunjukkan respons terbaik dan berbeda nyata dengan taraf $d_{1}$. Sedangkan perlakuan konsentrasi POC trubus menunjukkan pengaruh yang tidak bebeda nyata terhadap semua taraf perlakuan.

\section{Pembahasan}

Berdasarkan hasil analisis takaran pupuk kandang domba dengan konsentrasi POC trubus menunjukkan adanya interaksi pada tinggi tanaman umur 9 MST, jumlah polong per tanaman dan bobot polong pertanaman. Sedangkan untuk pengamatan tinggi tanaman umur 3 MST, 5 MST dan 7
MST, persentasi polong bernas per tanaman dan jumlah biji pertanaman tidak menunjukkan interaksi.

Terjadinya interaksi pada tinggi tanaman umur 9 MST, dimana taraf perlakuan $d_{3}$ (15 ton ha $\left.^{-1}\right)$ pada taraf POC trubus $\mathrm{p}_{1}\left(1 \mathrm{ml} \mathrm{l}^{-1}\right)$ memperlihatkan tinggi tanaman tertinggi dan berbeda nyata dengan perlkauan yang memiliki konsentrasi POC trubus tinggi. Dalam hal ini terjadi hubungan ke arah negatif artinya penggunaan takaran pupuk kandang domba yang tinggi menghendaki penggunaan konsentrasi POC trubus yang rendah. Efek interaksi ini diduga pada umur 9 MST tanaman memasuki fase pembungaan yang mana pada tanaman kacang tanah merupakan fase kritis, artinya tanaman membutuhkan unsur hara yang lebih tinggi untuk merangsang pembungaan, sehingga unsur hara yang diberikan baik yang bersumber dari pupuk kandang domba maupun POC trubus dimanfaatkan penuh oleh tanaman. Sementara ketersediaan unsur hara yang disuplai oleh pupuk kandang domba mulai berkurang. 
Tidak terjadinya interaksi pada tinggi tanaman umur 3 MST, 5 MST dan 7 MST disebabkan karena suplai ketersediaan unsur hara yang bersumber dari pupuk kandang domba masih mencukupi untuk pertumbuhan tanaman kacang tanah. sehingga secara efek madiri faktor takaran pupuk kandang domba menunjukkan perbedaan yang nyata pada umur 5 MST dan 7 MST terkecuali pada umur 3 MST. Taraf takaran pupuk kandang domba yang tinggi memperlihatkan tinggi tanaman terbaik dibandingkan dengan taraf yang menggunakan takaran rendah. Sedangkan faktor konsentrasi POC trubus menunjukkan perbedaan yang tidak nyata pada semua umur pengamatan. Keadan ini menunjukkan bahwa ketersediaan unsur hara tanaman sudah terpenuhi dengan adanya pemberian pupuk kandang domba sehingga meskipun diberikan konsentrasi POC trubus yang berbeda tanaman tidak memanfaatkan unsur hara tersebut.

Pengamatan persentase polong bernas per tanaman dan jumlah biji per tanaman tidak menunjukkan interaksi dan secara efek mandiri terlihat bahwa pemberian pupuk kandang domba memberikan perbedaan yang nyata, dimana takaran 10 ton $\mathrm{ha}^{-1}$ dan 15 ton ha $^{-1}$ memberikan jumlah biji per tanaman terbanyak. Hal ini terjadi karena dengan pemberian takaran pupuk kandang yang tepat dapat meningkatkan kesuburan tanah secara fisik, dimana dengan pemberian pupuk organik tanah akan menjadi lebih remah sehingga ginofor akan mudah masuk ke dalam tanah dan perkembangan polong dalam tanah menjadi lebih berkembang dengan baik. Bahkan bahan organik dapat mengubah tanah yang semula tidak berstruktur (pejal) dapat membentuk struktur yang baik atau remah, dengan derajat struktur yang sedang hingga kuat. (Scholes dkk, 1994).

Hasil analisi duncant pada pengamatan jumlah pong per tanaman dan bobot pong per tanaman menunjukkan adanya interaksi, dimana secara garis besar terlihat bahwa pemberian takaran pupuk kandang domba yang rendah menghendaki konsentrasi POC trubus yang tinggi begitupun sebalinya. Diketahui bahwa disamping hara, penambahan organik memperbaiki sifat fisik media Menurut Sutedjo (1995) bahwa fungsi bahan organik yaitu memperbaiki struktur tanah memperbaiki sifat fisik tanah yang besar pengaruhnya terhadap penyediaan unsur hara bagi tanaman, memperbaiki kehidupan mikroorganisme, memperbaiki tata udara dan air tanah, mengatur temperatur tanah dan meningkatkan pengaruh pemupukan dengan pupuk buatan. Dengan adanya peran bahan organik tersebut, maka terjadi sinergitas antara pemberian pupuk kandang domba dan konsentrasi POC trubus, asalkan dengan pemberian takaran dan konsentrasi yang tepat maka pemberian kedua jenis pupuk organik tersebut dapat meningkatkan hasil tanaman kacang tanah. 


\section{Kesimpulan dan Saran}

Pemberian takaran pupuk kandang domba dan konsentrasi POC trubus melihatkan adanya interaksi pada tinggi tanaman 9 MST, jumlah pong per tanaman dan berat polong per tanaman, pemberian takaran pupuk kandang yang tinggi menghendaki konsentrasi POC yang rendah.

Secara efek madiri pemberian takaran pupuk kandang 10 ton $\mathrm{ha}^{-1}$ dan 15 ton $\mathrm{ha}^{-1}$ menunjukkan pengaruh terbaik terhadap tinggi tanaman umur 5 MST dan 7 MST, persentase polong bernas serta jumlah biji per tanaman.

Perlu dilakukan penelitian lebih lanjut terhadap jenis varietas kacang tanah yang berbeda dan lingkungan tumbuh tanaman yang lebih variatif.

\section{Daftar Pustaka}

Direktorat Jenderal Tanaman Pangan. 2012. Road Map Peningkatan Produksi Kacang tanah dan Kacang Hijau Tahun 2010 2014.

Scholes, M.C., Swift, O.W., Heal, P.A. Sanchez, JSI., Ingram and R. Dudal, 1994. Soil Fertility research in response to demand for sustainability. In The biological managemant of tropical soil fertility (Eds Woomer, Pl. and Swift, MJ.) John Wiley \& Sons. New York.

$\begin{array}{lr}\begin{array}{c}\text { Sutedjo,M.M.,1995.Pupuk Dan } \\ \text { Pemupukan }\end{array} & \text { Cara } \\ \text { Cipta,Jakarta. } & \\ \text { Wijanarko A, Rahmianna } & \text { A.A, } \\ \text { Sudaryono. 2013. } & \text { Status } \\ \text { Kesuburan Lahan kering Alfisol } \\ \text { dan Usaha Peningkatan } \\ \text { Produktivitas Kacang } & \text { Tanah. } \\ \text { Pusat Penelitian } & \text { dan } \\ \text { Pengembangan } & \text { Tanaman } \\ \text { Pangan. Badan } & \text { Litbang } \\ \text { Pertanian. Bogor }\end{array}$

Yurnalis. 2006. Pengaruh Aplikasi Pupuk Organik dan Pupuk An Organik terhadap Pertumbuhan,

\footnotetext{
Penulis adalah Staf Pengajar di Fakultas Pertanian Unwim
} 